\title{
A chegada da Companhia Siderúrgica do Atlântico em Santa Cruz: Novo Desenvolvimentismo na Borda Metropolitana Fluminense
}

The Arrival of Companhia Siderúrgica do Atlântico in Santa Cruz: New

Developmentism at the Fluminense Metropolitan Edge

L'arrivée de la Companhia Siderúrgica do Atlântico à Santa Cruz: Nouveau

Développementisme à la Bordure Métropolitaine du Rio de Janeiro

La llegada de la Companhia Siderúrgica do Atlântico en Santa Cruz: Nuevo

Desarrollolismo en el Borde Metropolitano del Rio de Janeiro

\section{André Luiz do Nascimento Germano}

\section{OpenEdition}

Journals

\section{Edição electrónica}

URL: http://journals.openedition.org/espacoeconomia/16851

DOI: 10.4000/espacoeconomia. 16851

ISSN: 2317-7837

\section{Editora}

Núcleo de Pesquisa Espaço \& Economia

Refêrencia eletrónica

André Luiz do Nascimento Germano, « A chegada da Companhia Siderúrgica do Atlântico em Santa Cruz: Novo Desenvolvimentismo na Borda Metropolitana Fluminense », Espaço e Economia [Online], 19 | 2020, posto online no dia 01 setembro 2020, consultado o 10 setembro 2020. URL : http:// journals.openedition.org/espacoeconomia/16851; DOI : https://doi.org/10.4000/espacoeconomia. 16851

Este documento foi criado de forma automática no dia 10 setembro 2020.

(C) NUPEE 


\title{
A chegada da Companhia Siderúrgica do Atlântico em Santa Cruz: Novo Desenvolvimentismo na Borda Metropolitana Fluminense
}

\author{
The Arrival of Companhia Siderúrgica do Atlântico in Santa Cruz: New \\ Developmentism at the Fluminense Metropolitan Edge \\ L'arrivée de la Companhia Siderúrgica do Atlântico à Santa Cruz : Nouveau \\ Développementisme à la Bordure Métropolitaine du Rio de Janeiro \\ La llegada de la Companhia Siderúrgica do Atlântico en Santa Cruz: Nuevo \\ Desarrollolismo en el Borde Metropolitano del Rio de Janeiro
}

André Luiz do Nascimento Germano

\section{Introdução}

Nos anos 2000, o então Presidente Luiz Inácio Lula da Silva, principalmente em seu segundo mandato, promoveu a retomada do planejamento e execução de grandes obras de infraestrutura social, urbana, logística e energética do Brasil. Este artigo se debruça sobre a discussão das políticas dos governos do Partido dos Trabalhadores (PT), debatendo o que Mercadante (2010), em sua tese de doutorado, chamou de "novo desenvolvimentismo brasileiro", tendo a instalação da Companhia Siderúrgica do Atlântico em Santa Cruz, Rio de Janeiro, RJ como estudo de caso. Durante este período, em que o contexto político-econômico brasileiro foi marcado pelo que o autor chamou de novo desenvolvimentismo, os governos municipal, estadual e federal, juntamente com o empresariado nacional e internacional, construíram um imenso polo industrial e um complexo portuário voltado à exportação de commodities minerais e produtos siderúrgicos no Extremo Oeste Metropolitano Fluminense (OLIVEIRA, 2015). 0 primeiro empreendimento desse polo industrial, neste período, como mostra o Instituto Políticas 
Alternativas para o Cone Sul - PACS (2012), foi a Companhia Siderúrgica do Atlântico Ternium CSA. Inicialmente, a CSA pertencia à empresa alemã ThyssenKrupp; em 2017, a Ternium comprou a siderúrgica por 1,5 bilhão de euros ${ }^{1}$.

Para se ter uma ideia inicial das proporções do projeto, o PACS (2012) informa que somente o canteiro de obras da empresa, durante sua construção, correspondia à área dos bairros Ipanema e Leblon, juntos. Além da CSA, havia variados projetos, como expansão portuária e rodoviária e outros grandes empreendimentos do ramo metalsiderúrgico e logístico-petrolífero, caracterizando um momento atrativo para grandes empreendimentos do que se identifica como eixo Santa Cruz - Itaguaí-RJ.

3 A atuação da Ternium se deu especificamente no Distrito Industrial de Santa Cruz, transformando ferro em aço bruto e depois em placa de aço, um produto siderúrgico semiacabado e considerado de baixo valor agregado, com alto potencial poluidor durante seu processo de confecção. O Distrito Industrial de Santa Cruz, onde se instalou a empresa, foi inaugurado nos anos de 1970 (DAMAS, 2008), como consequência de projetos que calcaram na indústria e no desenvolvimentismo a política nacional, além de forte influência do contexto global de expansão geográfica do capitalismo. Na mesma conjuntura, para atender, principalmente, o distrito industrial, criou-se também o Porto de Sepetiba, atual Porto de Itaguaí, mais um importante investimento em infraestrutura daquele período, na busca de facilitar as dinâmicas de expansão do capital e da globalização que estava a se consolidar. A Companhia Siderúrgica do Atlântico iniciou suas obras no distrito industrial em 2005, entrando em dinâmico funcionamento a partir 2010.

4 Entende-se que é de vital importância expor o que o próprio economista e líder do Governo durante o período em análise expõe em sua discussão. Seu enfoque, analisando o contexto de tais políticas e ações do Estado, ajuda a entender e evidenciar as vantagens oferecidas à empresa; as mudanças nas dinâmicas espaciais do bairro e os investimentos em infraestrutura para as atividades do conglomerado industrial, siderúrgico e portuário; além de debater a consolidação do que Oliveira (2015) chama de Extremo Oeste Metropolitano Fluminense e do que se identifica como eixo Santa Cruz - Itaguaí.

5 Este artigo se estrutura em quatro momentos: o primeiro apresenta o contexto, com breve discussão do novo desenvolvimentismo sob a perspectiva de Mercadante (2010), de chegada da CSA em Santa Cruz; o segundo, desvenda as práticas do Estado brasileiro, em todas as suas instâncias, na atração da CSA para o eixo Santa Cruz - Itaguaí; o terceiro, apresenta algumas das transformações nas dinâmicas do bairro com a instalação da empresa e todo seu aparato técnico, mecanizando ainda mais o território (SANTOS, 1996); e o quarto apresenta as características da borda metropolitana, em tempos de metropolização do espaço (LENCIONI, 2015) e consolidação do Extremo Oeste Metropolitano Fluminense (OLIVEIRA, 2015).

\section{"Novo Desenvolvimentismo" e os Projetos para a Região}

Nossa escolha por Mercadante (2010) não é por acaso. O autor defendeu sua tese de doutoramento em Economia justamente no final do Governo Lula (PT), no qual foi líder no Senado Federal. No mesmo ano que se findou o governo, em 2010, foi dado início às 
atividades siderúrgicas da Ternium, em Santa Cruz, sendo uma consequência simbólica no contexto nacional da construção do polo industrial-portuário. Buscaremos criar uma ambientação do leitor com a conjuntura política e econômica da época analisada até 2010, além de vislumbrar algumas conceituações.

7 A centralidade da tese de Mercadante (2010) evidencia que no período de 2003-2010, houve, no Brasil, a emergência de um novo padrão de desenvolvimento, sendo substancialmente distinto tanto do neoliberalismo, quanto do antigo nacionaldesenvolvimentismo predominante no início da industrialização brasileira. $\mathrm{O}$ autor destaca a ruptura paradigmática com a agenda liberal hegemônica na América do Sul desde os anos noventa, colocando o social como eixo estruturante do tal novo desenvolvimentismo.

8 Para essa ruptura paradigmática a estratégia foi lançar a "Carta ao Povo Brasileiro" ${ }^{\text {, }}$ concebida em um momento em que a economia brasileira era estremecida pelo mercado financeiro. A economista Laura Carvalho (2018) afirma que o pânico financeiro gerado pelo temor de uma mudança brusca na política econômica levou o dólar de 2,60 reais no início de 2002 a 4,00 reais às vésperas da eleição de Luiz Inácio Lula da Silva. Mercadante (2010) salienta que a carta representou, portanto, o compromisso petista de responsabilidade política com uma transição gradual dos programas neoliberais anteriores para as novas diretrizes políticas que estavam assinaladas no programa de governo proposto por Lula, para preservar a estabilidade monetária num contexto de insegurança e incertezas com o futuro. Era uma tática para vencer a eleição, mas, também, uma face moderada de um partido que analisou a conjuntura e se adaptou.

Com a eleição vencida, essa opção pela transição e não ruptura drástica não foi muito bem aceita pela base do PT, que esperava maiores transformações já nos primeiros anos de governo, em que houve desentendimentos e discordâncias na área econômica em alas diferentes do governo, principalmente entre a Casa Civil, chefiada por José Dirceu, e o Ministro da Fazenda, com Antonio Palocci. Em 2004, inclusive, a Executiva Nacional do PT defendeu mudanças mais profundas, voltadas para a retomada do desenvolvimento, que é palavra unificadora, com geração de emprego e distribuição de renda (CARVALHO, 2018). No entanto, mesmo sob algumas dificuldades, com o passar do tempo e as incertezas ficando para trás, o governo foi instituindo suas políticas de forma gradual, aproveitando a conjuntura internacional favorável, devido ao aumento dos preços das commodities. Entre 2003 e 2005, ainda no primeiro mandato, a principal novidade se deu no âmbito das políticas de transferência de renda, expandidas e universalizadas com a criação do programa Bolsa Família e as novas políticas de salário mínimo voltadas para a base da pirâmide, aumentando a distribuição de renda (CARVALHO, 2018).

10 O Estado, assim, efetivou uma massiva transferência de renda para os setores mais pobres e desprotegidos, numa recuperação sistemática do nível de emprego e do poder de compra do salário mínimo, na popularização do crédito para os segmentos antes excluídos dos processos, bem como, em uma série de outros programas direcionados a distribuir renda, a gerar oportunidades e a promover a inclusão social. Tais políticas foram a base e condicionaram, posteriormente, o que Carvalho (2018) chamou de milagrinho brasileiro. A autora afirma que o maior acesso ao crédito e maiores investimentos público em infraestrutura física e social, ofertados pelo Estado, foram os pilares que alimentariam esse processo de crescimento mais inclusivo e com grande apelo junto à opinião pública. 
11 Dessa forma, o social, que nas políticas nacionais-desenvolvimentistas do passado era colocado de lado, para Mercadante (2010) passou a se constituir em um dos eixos estruturantes desse novo modelo de desenvolvimentismo. Essa característica simbolizava uma ruptura com as políticas predominantemente neoliberais no Brasil e marcava uma era de crescimento associado à distribuição de renda, jogando por terra a ideia das décadas de 1960-70, famosas por afirmações de que primeiro se deveria fazer crescer o bolo, para depois dividi-lo. Não havia sido implementado, até então, um processo de acumulação que combinasse crescimento com distribuição sistemática e continuada da renda, com inclusão social e a redução da pobreza como meta.

Mercadante (2010) cita Celso Furtado, ao afirmar que o subdesenvolvimento era um problema essencialmente político e que na democracia fortalecida e consolidada não haveria subdesenvolvimento. Para o ex-senador, no entanto, a constituição do novo desenvolvimentismo no Brasil foi dada no contexto do aperfeiçoamento das instituições republicanas, da expansão dos direitos econômicos e sociais da população e, ainda, do alinhamento às reivindicações dos movimentos sociais nas políticas públicas brasileiras. Portanto, o fortalecimento das instituições e ferramentas democráticas seriam características deste modelo de desenvolvimento.

13 A nova forma de inserção internacional do país é de fundamental relevância à geração das condições necessárias na consolidação de um novo padrão desenvolvimentista brasileiro. Durante o período nacional-desenvolvimentista do século XX, a política externa buscou, com algumas exceções, a afirmação autônoma do Brasil em negociações bilaterais, mantendo, no entanto, presença de organismos multilaterais. A principal preocupação dessa política, ao longo dos anos 1960 e 1970, era colocar os temas do desenvolvimento e do subdesenvolvimento, da transferência de tecnologia e da superação das desigualdades entre os países, como assuntos primordiais das relações internacionais (MERCADANTE, 2010). Entretanto, essa política externa foi abandonada ao longo do período de predomínio neoliberal dos anos de 1990 e, baseando-se nas políticas do Estado Mínimo, foi substituída por outra que colocou ênfase na integração do país ao "processo de globalização" e no reconhecimento do status de simples potência média regional para o Estado brasileiro. 0 pressuposto dessa política era de que o Brasil - inserindo-se na globalização ascendente e à nova ordem internacional orientada pelos interesses estratégicos do mundo ocidental e superando o suposto isolamento provocado pelo nacionalismo desenvolvimentista - participaria mais do comércio e da prosperidade "mundializada", podendo usufruir dos avanços tecnológicos. No entanto, como atesta Mercadante (2010, p. 31), não foi exatamente isso que aconteceu:

Na realidade, a consequência maior da política externa vinculada ao paradigma do Estado Mínimo foi, além da diminuição de nossa participação no comércio mundial, a redução do protagonismo regional e internacional do país. De fato, a fragilidade econômica vigente no período, a baixa prioridade da política de defesa, a estagnação e os impasses do Mercosul, a inexistência de avanços concretos na integração sul-americana, o abandono parcial do eixo horizontal (Sul-Sul), o baixo investimento em parcerias estratégicas com países emergentes, a falta de enfrentamento das ameaças aos interesses do país, além do alinhamento aos ditames da nova ordem mundial centrada na única superpotência, fizeram o Brasil perder a sua capacidade de projetar os seus interesses no exterior.

No governo Lula, entretanto, o círculo neoliberal foi rompido da forma que se fez na década anterior. A política externa e de comércio exterior passou a diversificar as parcerias econômicas e comerciais, sendo fundamental para superação da 
vulnerabilidade externa da economia, que era fator de fragilização do Brasil internacionalmente. Mercadante (2010) salienta que as novas políticas externas baseadas no novo desenvolvimentismo, para além da valorização das commodities, possibilitou uma estabilidade macroeconômica no país. Internamente, através da distribuição de renda, promoveu maior inclusão social e dinamização do mercado interno de massa e externamente se fortaleceu, buscando por novos espaços, além de iniciar uma redução das irregularidades políticas, econômicas e comerciais entre as nações.

15 Mercadante (2010) cita ainda a importância das estratégias na geopolítica do petróleo, evidenciado com a descoberta dos campos do Pré-Sal, como oportunidade de afirmação de sua posição de destaque no cenário internacional. 0 autor advoga, então, por um novo marco regulatório do petróleo que possibilitasse a Petrobras viabilizar a exploração do petróleo recentemente descoberto (plataformas, navios, novos portos, gasodutos, etc.), impactando positivamente a indústria nacional. Em seguida, aponta cinco grandes barreiras a ultrapassar para consolidar o novo desenvolvimentismo no Brasil: o desafio da infraestrutura e logística precárias, a eliminação da pobreza e da desigualdade social; e o desafio da inserção internacional soberana. Esses três primeiros desafios foram sendo enfrentados até o ano de 2010 com êxito, segundo o autor.

Os outros dois desafios seriam a criação de uma sociedade do conhecimento, com o objetivo de superar os baixos índices educacionais herdados de séculos de desigualdades, que acarretava na falta de inovação e pesquisa mais elevadas no país; e os desafios da sustentabilidade ambiental e da transição para a economia verde que, se não fossem vencidos, dificultariam o crescimento sustentado numa perspectiva de longo prazo. No entanto, ele mesmo aponta a dificuldade da superação desses dois últimos, em 2010, na agenda interna, quer pelo caráter inédito das questões, quer pelos estrangulamentos financeiros em que o país se encontrava.

Vale destacar que o foco nas questões ambientais no novo desenvolvimentismo de Mercadante (2010) não se deu por acaso. Qualquer projeto de país e ou sociedade que se coloque como novo, depois do auge das tensões e discussões ambientais na segunda metade do século XX (OLIVEIRA, 2019), precisa evidenciar tais preocupações, mesmo que, no fim, sejam apenas apêndices ou espaços para empresas desenvolveram projetos que melhorem suas imagens no mercado, como ocorrido a partir da década de 1990: vislumbram-se gigantescos mercados para certos setores ambientais e abrem-se espaços para empresas altamente poluidoras desenvolverem projetos de preservação de florestas, apoiando entidades ambientalistas, incentivando educação ambiental nas escolas e se dizendo sustentáveis.

18 É neste cenário político-econômico-social nacional, com o Estado se colocando como agente central numa nova investida desenvolvimentista, com características singulares e peculiaridades históricas, que o Estado brasileiro e empresas nacionais e internacionais construíram um polo industrial e um complexo portuário voltado para a exportação de commodities minerais e produtos siderúrgicos no eixo Santa Cruz Itaguaí, doravante, no Extremo Oeste Metropolitano Fluminense (OLIVEIRA, 2015). O primeiro e mais emblemático empreendimento foi a Ternium - Companhia Siderúrgica do Atlântico (CSA), cujo processo para instalação do que se pretendia a maior siderúrgica da América Latina iniciou-se em 2005 (PACS, 2009).

19 As obras da Ternium CSA foram seguidas dos processos de licenciamento dos seguintes projetos na região: Porto Sudeste da LLX Logística, com capacidade de escoamento de 
50 milhões de toneladas de minério do quadrilátero ferrífero; ampliação do Porto de Itaguaí; construção de porto e estaleiro de submarinos nucleares da Marinha do Brasil; construção de um mega porto compartilhado entre Petrobras, Gerdau e Companhia Siderúrgica Nacional - CSN; expansão da capacidade produtiva da Gerdau-Cosigua e construção da nova usina de aços especiais (PACS, 2009). Todos estes projetos faziam parte da execução de megaprojetos que visavam o crescimento econômico, através da exploração de recursos naturais, em particular commodities agrícolas e minerais, com base neste novo desenvolvimentismo implantado na primeira década do século pelo PT. A figura a seguir aponta os projetos/empreendimentos no eixo Santa Cruz - Itaguaí. ${ }^{3}$

Figura 1: Mapa com os projetos industriais, portuários e rodoviários planejados para a Baía de Sepetiba, no eixo Santa Cruz - Itaguaí.

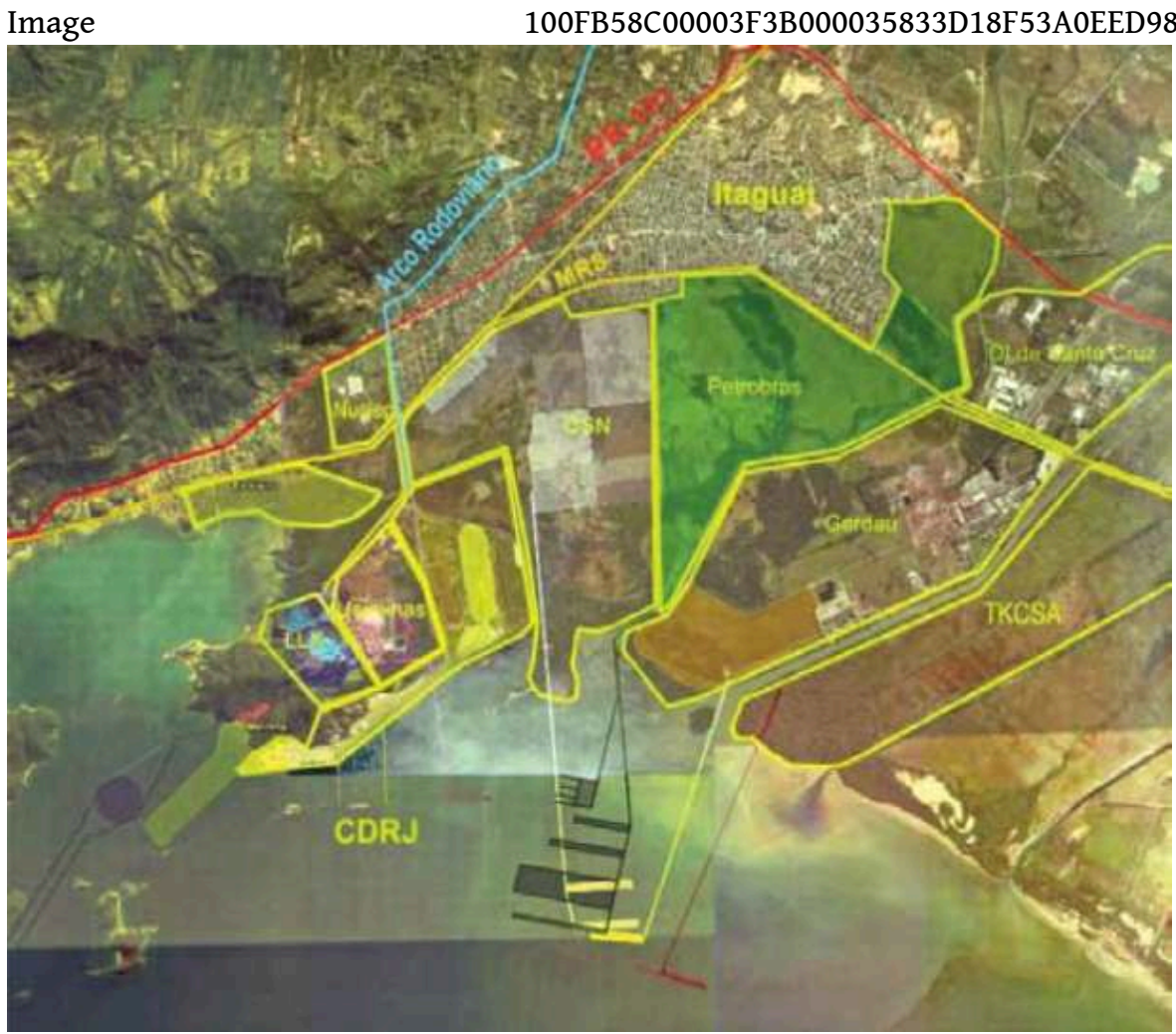

Fonte: PACS, 2012. Adaptado

\section{A Instalação da Companhia Siderúrgica do Atlântico e a Guerra dos Lugares}

Santos (1996, p. 244) afirma que "os negócios governam mais que os governos e com a globalização da tecnologia e da economia, os Estados aparecem como servos das corporações multinacionais". Os lugares passam a se distinguir pela diferente capacidade de oferecer rentabilidade aos investimentos. Essa rentabilidade é maior ou menor dependendo dos equipamentos de infraestrutura, acessibilidade, de leis, impostos, relações trabalhistas, etc. Há, portanto, de acordo com o autor, uma guerra global entre os lugares. 
21 O leitor então pergunta: “por que começar este item, que no título se mostra pretender explorar a instalação da CSA em Santa Cruz, falando de guerra entre os lugares?". Porque por mais que o Estado se proponha a estruturar um modelo de desenvolvimento, que tenha perspectivas novas e esteja preocupado com a superação de questões que envolvam as desigualdades sociais, como Mercadante (2010) afirma ter ocorrido nos dois mandatos de Lula, regras do sistema econômico internacional não poderiam ser rompidas facilmente, principalmente pós-ascensão neoliberal. Santos (1996) afirma haver, muitas vezes, uma busca do Estado para assegurar o bem-estar social em épocas de globalização exacerbada. Na verdade, a lógica da guerra dos lugares é aquela na qual qualquer país que queira participar ativamente da globalização contemporânea precisa se submeter e participar, com maior ou menor intensidade.

Santos (1996) chama atenção ainda para os territórios nacionais que se transformam num espaço nacional da economia internacional, pois os sistemas de engenharia mais modernos são criados nos países, muitas vezes com investimentos pesados dos próprios Estados, no entanto sãos mais usados pelas firmas transnacionais que pela própria sociedade nacional. Os lugares, assim, se especializam em virtude de suas facilidades naturais, de suas realidades técnicas e questões de ordem social, para darem maior segurança e rentabilidade para capitais, em sua maioria estrangeiros. De um lado, empresas buscam os melhores sítios para suas instalações, com melhores localizações que facilitem os lucros; de outro, temos os próprios lugares se especializando e se adaptando, para atrair investimentos dessas empresas. Nesse contexto, o Estado tem um papel vital, pois é quem prepara o terreno, adapta leis (ambientais e trabalhistas), investe em infraestrutura e faz o máximo possível na tentativa de atrair determinados investimentos.

23 Sendo assim, a importância do território aumenta com a globalização, pois se as técnicas contemporâneas tornaram possível multiplicar a produtividade, somente o faz porque os lugares se diferenciam justamente pela capacidade de oferecer às empresas maior ou menor produtividade. É como se o território constituísse um acúmulo de fluxos de mais-valia, depositando valor às empresas nele sediadas. Em um artigo ${ }^{4}$ publicado na Folha Online, Santos (1999) salienta que por isso as maiores empresas definem, nos diferentes países, pontos que facilitem seus lucros, exigindo, do Estado e seus representantes, equipamento local e regional adequado às suas atividades e aperfeiçoamento de suas ligações mediante elos materiais e informacionais modernos, além de adaptação política. Os lugares, então, lutam entre si para atrair novos empreendimentos, obedecendo lógicas globais que impõem aos lugares e países "uma nova medida do valor, planetária e implacável" (SANTOS, 1999).

No contexto interno brasileiro, caracterizado por este novo desenvolvimentismo rompendo gradualmente com o neoliberalismo dos anos de 1990, coube ao Estado financiar diretamente, via Banco Nacional do Desenvolvimento Econômico e Social (BNDES), conceder isenções fiscais e oferecer infraestrutura necessária, como energia elétrica subsidiada, abertura de estrada e construção de portos, favorecendo o empresariado nacional e internacional. O BNDES ganhou destaque neste modelo de desenvolvimento, passando a atuar como a principal fonte de financiamento de longo prazo no Brasil (PACS, 2012). Os investimentos diretos passaram de cerca de 20 bilhões em 1999 para, aproximadamente, 168 bilhões em 2010 (Fig. 2): 
Figura 2: Gráfico da evolução de desembolso do BNDES em bilhões de reais.

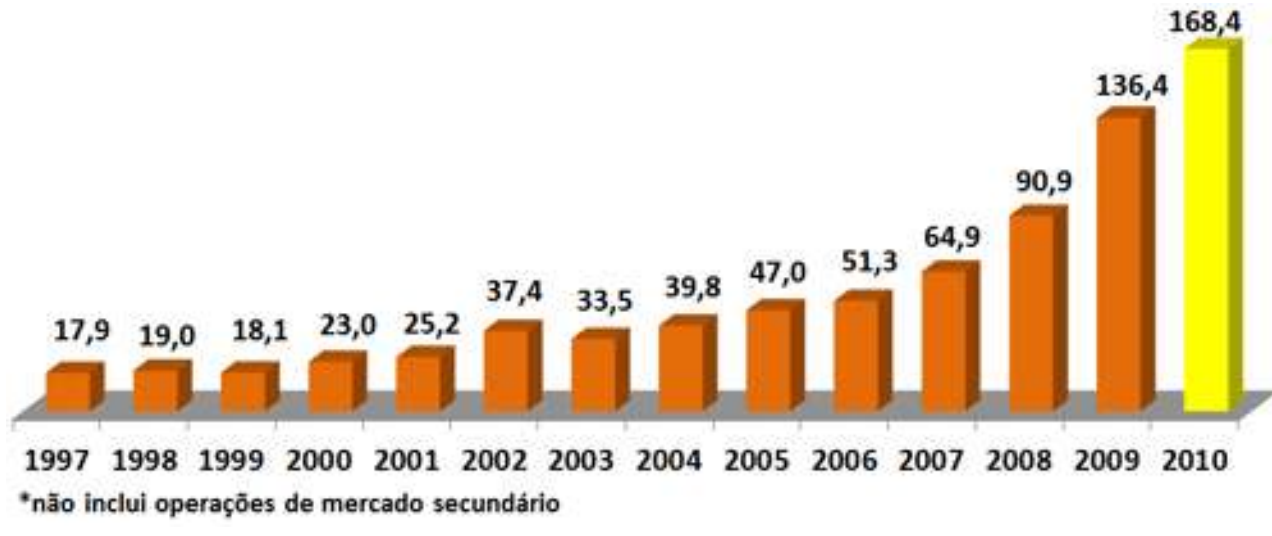

FONTE: BNDES. DISPONÍVEL EM: < HTTPS://WWW.BNDES.gOV.BR>. ACESSO EM: 22/01/2020.

Todo esse contexto de investimentos, trazendo especialização aos lugares, proporcionou ao Estado do Rio de Janeiro megaempreendimentos relacionados principalmente ao setor petrolífero, devido, em larga medida, à exploração da camada do Pré-Sal, bem como ao setor siderúrgico e portuário, com a região da Baía de Sepetiba sendo um dos destinos principais destes projetos. Destaca-se, entretanto, que durante os governos de Fernando Henrique Cardoso, o Porto de Sepetiba já havia recebido investimentos, com o objetivo de modernizá-lo e conectá-lo ainda mais com à globalização contemporânea.

Em seu Relatório Anual de 2011, o BNDES apresenta um gráfico que ilustra seus investimentos entre 2008 e 2011, principalmente no Sudeste, sendo 2010 o ano de maior destaque (Fig. 3).

Figura 3: Desembolso regional 2008-2011.
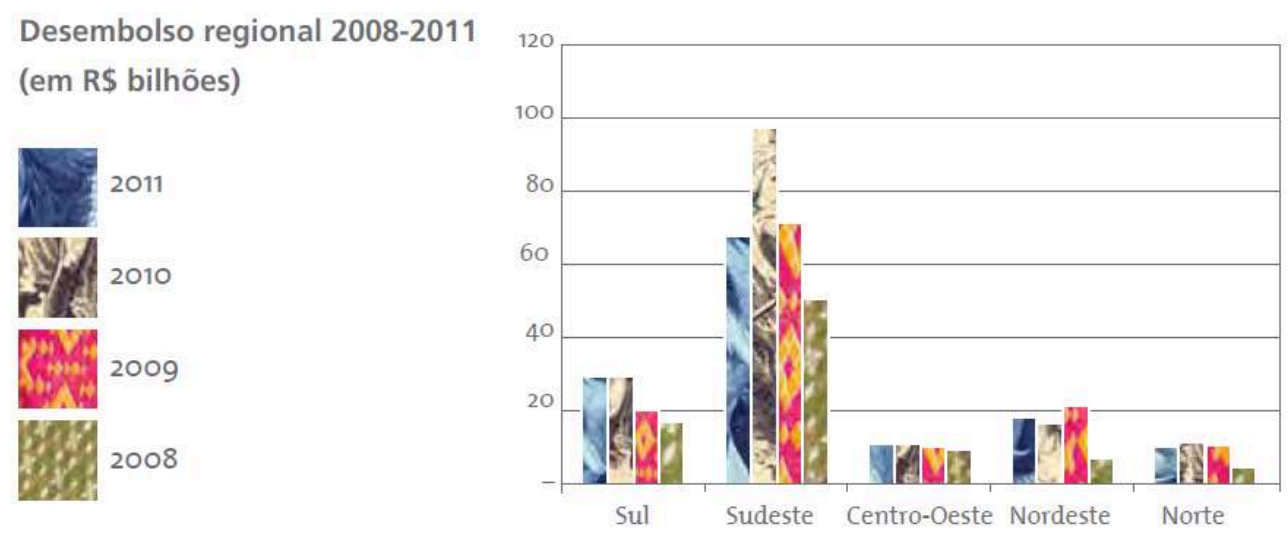

Fonte: Relatório Anual BNDES, 2011. Disponível em: < https://www.bndes.gov.br>. Acesso em: 22/01/2020

Apresentando brevemente três importantes exemplos, percebe-se, na página do BNDES, uma preocupação, na lógica industrial, do Estado brasileiro com a região durante o período abordado. Uma notícia ${ }^{5}$ de julho de 2005 chama à atenção o financiamento de R\$ 332,8 milhões para obras da CSN no, ainda, Porto de Sepetiba. No terminal, seriam realizadas a expansão e adequação da malha ferroviária e do sistema de descarregamento dos trens, bem como obras no pátio de estocagem, no sistema de 
peneiramento e nos sistemas de transportes terrestres e de carregamento de navios. A notícia apontava a CSN como um dos maiores e mais competitivos complexos siderúrgicos integrados do mundo, com capacidade de produção de 5,8 milhões de toneladas anuais de aço bruto na Usina Presidente Vargas, em Volta Redonda-RJ, além de destacar que a estratégia de expansão da CSN envolvia a perspectiva de aquisição de ativos no exterior e o desenvolvimento dos negócios relacionados à logística, cimento e à mineração de ferro. O texto salientava que a empresa, constituída pelo governo federal em 1941, entrou em operação em 1946, tendo seu processo de privatização concluído em 1994, com a ascensão do neoliberalismo brasileiro.

Ainda na página do BNDES, uma notícia ${ }^{6}$ de janeiro de 2010 mostra que o banco havia aprovado financiamento de $\mathrm{R} \$ 407,7$ milhões para construção do Porto Sudeste. O montante investido seria para a LLX Sudeste Operações Portuárias Ltda. adquirir equipamentos nacionais para o empreendimento. 0 porto, com área de 512 mil metros quadrados, seria dedicado à movimentação de minério de ferro e teria capacidade de movimentação de 50 milhões de toneladas de minério por ano. $O$ projeto foi aprovado no âmbito do Programa de Sustentação do Investimento (BNDES-PSI), com taxas de juros fixas de $4,5 \%$ ao ano para a aquisição de bens de capital. O financiamento do BNDES correspondia a $80 \%$ do investimento total em máquinas e equipamentos, de R\$ 509,6 milhões, destacando-se carregadores de navios, empilhadeiras, viradores de vagão e correias transportadoras. Segundo a página, o Porto Sudeste seria destinado principalmente ao escoamento da carga de minério de ferro da empresa MMX (também do grupo EBX), proveniente das minas de Minas Gerais.

Uma última notícia ${ }^{7}$, de junho de 2007 , a mais importante para esta pesquisa, destaca o fato de o BNDES financiar, com $\mathrm{R} \$ 1,48$ bilhão, o complexo siderúrgico da ThyssenKrupp Companhia Siderúrgica do Atlântico (TK-CSA), atual Ternium-CSA, em Santa Cruz. Conforme a figura 2 apresentada anteriormente, neste mesmo ano os investimentos do banco em escala nacional obtiveram um número recorde, chegando a 64 bilhões de reais. O crédito correspondia a $18 \%$ do investimento total do projeto da CSA, de R $\$ 8$ bilhões, sendo o maior empreendimento no setor siderúrgico brasileiro dos últimos vinte anos e o maior investimento, na época, da alemã ThyssenKrupp em sua estratégia de ampliação da produção de aço no mercado do Atlântico.

Os recursos do BNDES seriam destinados à aquisição de máquinas e equipamentos nacionais, obras civis, instalações e montagens associadas. O site destaca que a TK-CSA era uma associação entre a siderúrgica ThyssenKrupp Steel AG - TKS, acionista majoritária, e a mineradora brasileira Companhia Vale do Rio Doce - CVRD. Além da usina de aço, o investimento previa a construção de um porto próprio da CSA para a importação de carvão e exportação da sua produção. A TKS detinha, de início, $90 \%$ do capital e a CVRD 10\% de participação. Ou seja, uma associação entre um grande grupo siderúrgico alemão e a maior mineradora mundial de minério de ferro daquele período. A CVRD, que também foi privatizada durante os anos de 1990, participava do projeto visando garantir mercado para o seu minério de ferro e depois, segundo Guimarães (2011), aumentou sua participação, chegando em 2010, ano da inauguração, com 26,7\% das ações.

31 A publicação do BNDES destaca ainda que a localização da usina, próxima à linha ferroviária, permitiria a aquisição de minério de ferro a custos competitivos. Segundo ela, a eficiência da CSA também se daria com o aproveitamento da infraestrutura existente no Porto de Itaguaí, possibilitando a implantação de terminal portuário 
próprio - denominado Terminal Portuário Centro Atlântico - ao lado da usina, facilitando, assim, a importação de carvão metalúrgico e a exportação da sua produção com menores custos logísticos.

Além deste imenso financiamento do BNDES, o megaempreendimento ainda recebeu benefícios do Fundo de Desenvolvimento Econômico e Social - FUNDES, através da Lei $\mathrm{n}^{\circ} 4529$, de 31 de março de 2005. 0 Artigo $1^{\circ}$ dizia:

Fica aprovado o enquadramento das sociedades CSA COMPANHIA SIDERÚRGICA DO ATLÂNTICO, THYSSENKRUPP STAHL A. G e COMPANHIA VALE DO RIO DOCE e das sociedades integrantes do Complexo Siderúrgico, das quais elas participem, ainda que minoritariamente, no PROGRAMA DE ATRAÇÃO DE INVESTIMENTOS ESTRUTURANTES - RIOINVEST, instituído pelo Decreto no 23.012, de 25 de março de 1997, e suas posteriores alterações, para utilizar os recursos do Fundo de Desenvolvimento Econômico e Social - FUNDES, para a construção e operação de um Complexo Siderúrgico no Estado do Rio de Janeiro (Art.1², Lei nº 4529).

A Lei ainda conferiu isenção de Imposto sobre Operações relativas à Circulação de Mercadorias e sobre Prestações de Serviços de Transporte Interestadual ou Intermunicipal e de Comunicação (ICMS), ou outro tributo que o substitua, nas fases de construção, pré-operação e operação do Complexo Siderúrgico. Segundo o Ministério Público do Estado do Rio de Janeiro (MP-RJ), apenas em ICMS, a CSA teria deixado de pagar ao governo fluminense $R \$ 695$ milhões entre 2007 e 2010, usando de isenções tributárias 8 .

Os benefícios com o Poder Público não pararam por ai: a empresa contou com outras isenções ficais, como, por exemplo, do Imposto Sobre Serviços (ISS), oficializada em junho de 2006, com o a Lei Municipal n.4372/2006, no qual concede incentivos fiscais à construção e à operação de terminais portuários relacionadas à implementação de complexo siderúrgico na Zona Oeste do Município do Rio de Janeiro. Esta isenção de ISS ainda foi prorrogada, pela Lei municipal 5.133/2009. Houve também isenção de Imposto sobre Produtos Industrializados, PIS e Cofins. Iara Moura e Isabelle Rodrigues (2018) salientam, através de publicação no Le Monde Diplomatique Brasil ${ }^{9}$, que quando somados o financiamento do BNDES com os valores relativos a todas as isenções fiscais, totalizam cerca de $\mathrm{R} \$ 5$ bilhões de recursos públicos investidos na Companhia Siderúrgica do Atlântico, de todas as esferas do Estado brasileiro.

Os governos federal, estadual e municipal participaram, portanto, diretamente do processo de atração e instalação da empresa, com as práticas da guerra dos lugares sendo amplamente utilizadas para atrair e estabelecer o megaempreendimento siderúrgico. Segundo relatório do PACS (2012), antes de chegar ao Rio de Janeiro, a intenção era construir o empreendimento em São Luís do Maranhão, onde encontrou forte resistência e mobilização de ambientalistas, sindicatos, moradores, pesquisadores, religiosos, movimentos sociais e ministérios públicos, num movimento chamado "Reage São Luís", que se colocava contra a instalação de um complexo siderúrgico. Houve enfrentamento em diversas instâncias e as empresas envolvidas precisaram abrir mão de seus planos de instalação no Maranhão. Foi então que o Estado do Rio de Janeiro negociou a vinda da siderúrgica para Santa Cruz, iniciando os trabalhos para sua instalação em 2005. A figura a seguir mostra as estruturas da CSA ainda em construção. (Fig. 4). 
Figura 4: CSA, em Santa Cruz, ainda em construção.

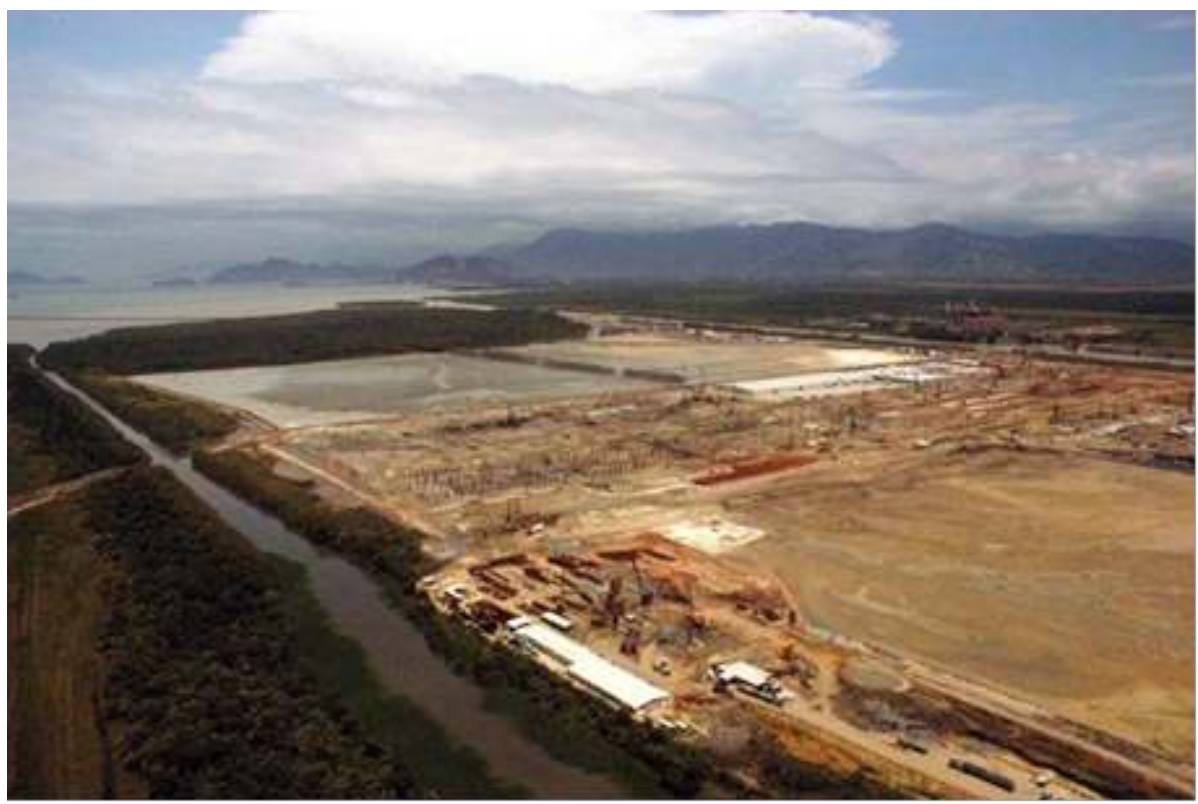

Fonte: Fotos e Vídeos das obras da CSA - Thyssen. Disponível em: <https://diariodorio.com/fotos-evdeos-das-obras-da-csa-thyssen/>. Acesso em: 04/02/2020.

No dia 18 de junho de 2010, a CSA foi inaugurada em Santa Cruz. Na cerimônia estiveram presentes o CEO da ThyssenKrupp, Ekkehard Schulz, o presidente Luiz Inácio Lula da Silva, o governador do Rio de Janeiro, Sérgio Cabral, o prefeito do Rio de Janeiro, Eduardo Paes, o presidente da Vale Roger Agnelli, entre outros membros do executivo e do legislativo nacional, estadual e municipal. Na figura 5, é possível observar algumas das autoridades presentes na inauguração. A presença dessas autoridades na cerimônia e suas respectivas falas, evocam novamente a percepção de que num período da humanidade onde os limites fronteiriços das nações não interrompem o fluxo de grandes quantidades de capital, Estados e companhias atuam de maneira conjunta e incisiva na busca por oportunidades de investimento. 
Figura 5: Autoridades presentes na inauguração da CSA em Santa Cruz.

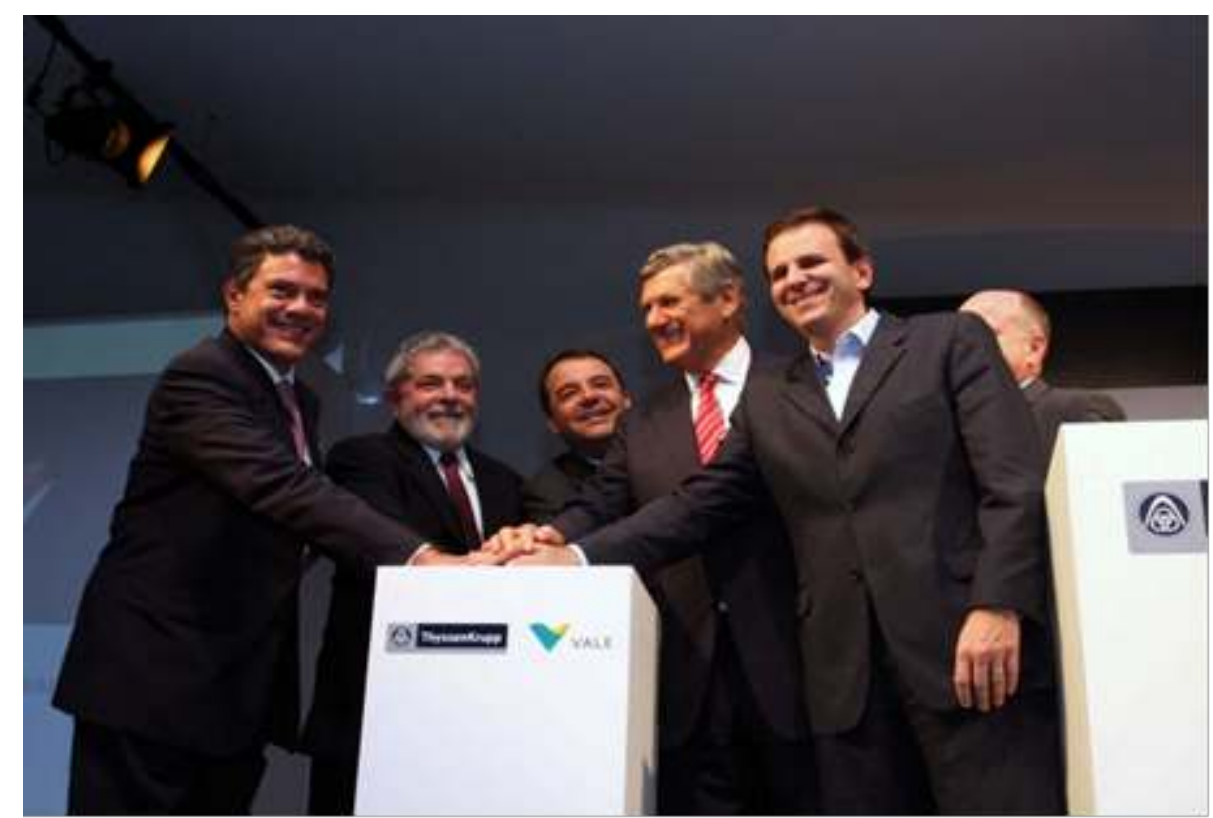

FONTE: COMPANHIA SIDERÚRgICA DO ATLÂNTICO É INAUgURADA NA ZONA OESTE DO RIO. DISPONÍVEL EM: < HTTP://RIODEJANEIRO.RIO/WEB/gUEST/EXIBECONTEUDO?ID=888394>. ACESSO EM: 04/02/2020.

O CEO da ThyssenKrupp ressaltou a importância da fábrica para o desenvolvimento da região de Santa Cruz, trazendo novamente para o centro do debate a palavra chave que justificou a industrialização da região no século XX, além de elogiar a parceria entre as três esferas do governo brasileiro ${ }^{10}$. $O$ presidente Lula afirmou que o projeto era muito importante para o desenvolvimento da indústria siderúrgica no Brasil e agradeceu a empresa alemã por não ter parado as obras no momento da crise internacional, além de destacar que o Brasil vivia uma situação econômica confortável e o povo brasileiro passava por um momento fenomenal. Já o governador Sérgio Cabral afirmou que desde o início fez um grande esforço tributário, através de incentivos e isenções fiscais, para que o projeto da siderúrgica fosse viabilizado ${ }^{11}$. É fato que relações estreitas com governos se desenrolam desde a esfera federal até a municipal. 0 próprio terreno onde a usina e o porto privativo se alojaram foi uma doação pública estadual (PACS; JUSTIÇA GLOBAL, 2017).

Ainda na inauguração, o presidente da República, em seu emocionado discurso, disse a seguinte frase: "o Brasil saberá agradecer o que vocês fizeram acontecer neste país hoje" (PACS; Justiça Global, 2017, p.29). Por sua origem no movimento sindical do ABC paulista, Lula manteve ao longo da carreira política um discurso de que a população de baixa renda não tem tempo a perder e precisa de melhoria de vida - seja pelo aumento do salário mínimo ou pelos programas sociais ou pela conquista de um emprego em linha de fábrica. Destaca-se, entretanto, que na área onde a empresa se instalou, viviam, desde cinco anos antes do início das obras da empresa, 75 famílias ligadas ao Movimento dos Trabalhadores Rurais sem Terra - MST, que retiravam da produção agrícola, no local, seu sustento (PACS, 2012), fato que foi ignorado pelas autoridades brasileiras, que intimaram as famílias a deixarem a região, mesmo durante o período em que o governo federal dizia praticar um novo desenvolvimentismo no Brasil, tendo, em sua base, ampla preocupação com questões sociais. A retirada do acampamento dos trabalhadores rurais sem-terra, de um movimento historicamente ligado ao mesmo 
campo político do PT, para a instalação de uma siderurgia com capital global, é de fato uma contradição já nos primórdios do megaempreendimento em Santa Cruz.

\section{Objetos e Ações: a Siderúrgica e Sua Potencialidade Técnica}

Instalado em Santa Cruz, o conglomerado industrial-siderúrgico-portuário possui usina siderúrgica integrada, com capacidade de produção de até 10 milhões de toneladas de placas de aço por ano; usina termoelétrica, para geração de $490 \mathrm{MW}$ de energia elétrica, alimentada por quatro milhões de toneladas de carvão mineral; um porto, com dois terminas - um para chegada de matéria prima e outro para saída de mercadorias composto por uma ponte de acesso de $4 \mathrm{~km}$ e um píer de $700 \mathrm{~m}$ que atravessa o manguezal e o oceano (PACS, 2012). As figuras a seguir apresentam parte da estrutura física implantada em Santa Cruz pela CSA; as 7 e 8 a partir de fotos retiradas de um vídeo disponibilizado pela Companhia ${ }^{12}$, publicado com o objetivo de apresentar o processo siderúrgico que envolve instalações de última geração, segundo a descrição (Figs. 6 a 8).

Figura 6: Estrutura da siderurgia vista pelo alto. Fonte: Chuva de prata na Baía de Sepetiba.

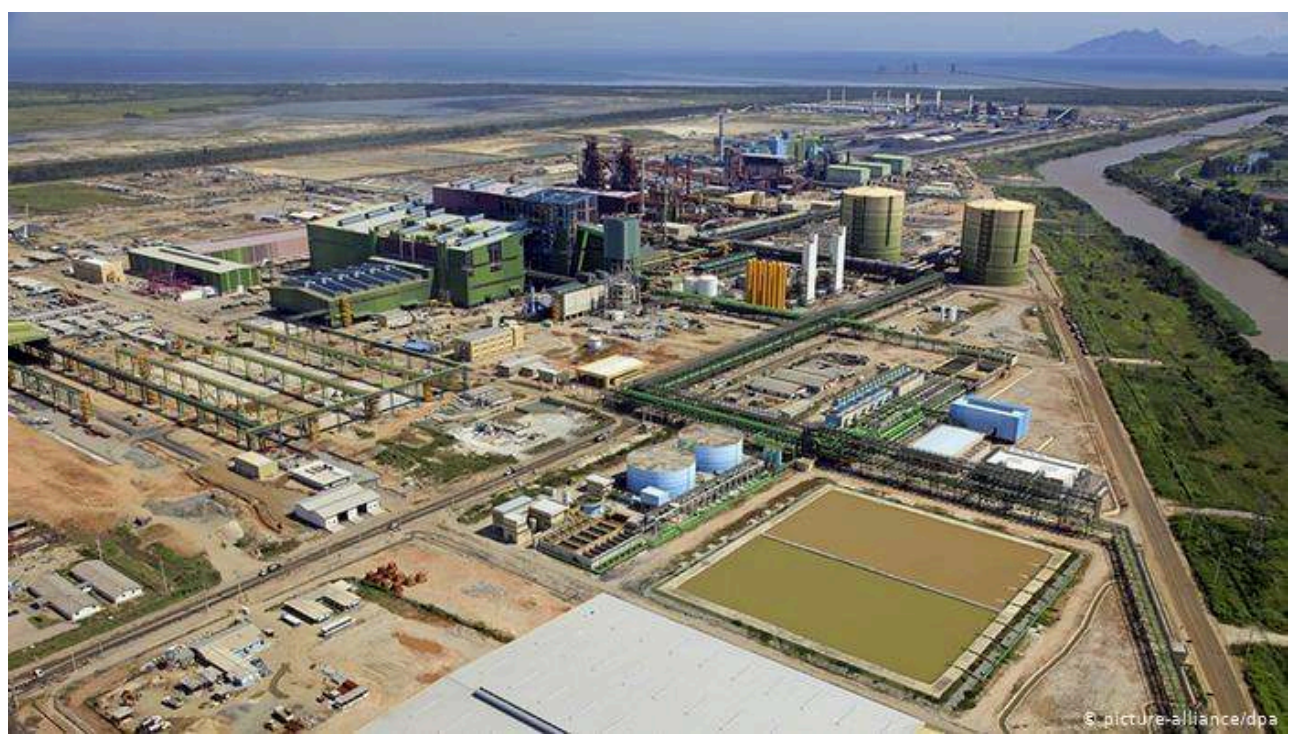

Disponível em: < https://www.dw.com/pt-br/chuva-de-prata-na-ba\%C3\%ADa-de-sepetiba/ a-16378347>. Acesso em: 04/02/2020. 


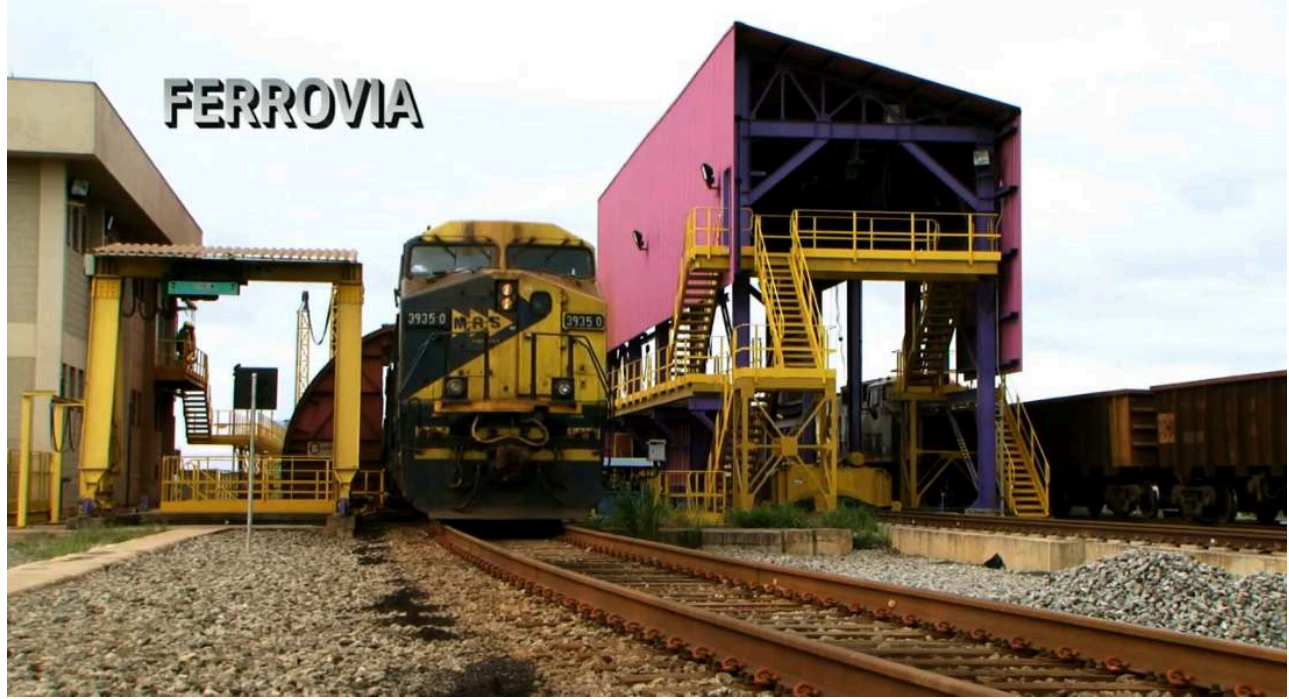

Fonte: Canaltkcsa. Disponível em: <https://www.youtube.com/watch?v=bUiBC8c1h4M>. Acesso em: 04/02/2020.

Figura 8: Um dos terminais portuários usados pela CSA em Santa Cruz.

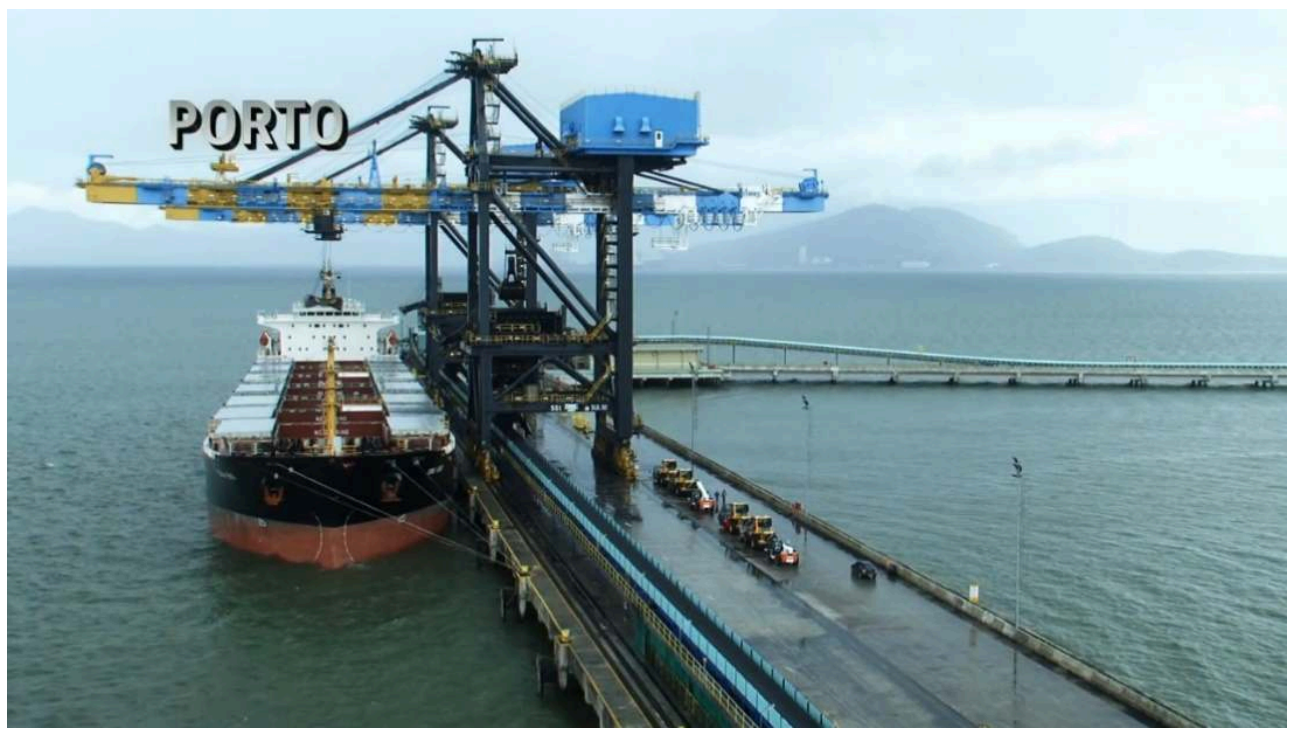

Fonte: Canaltkcsa. Disponível em: <https://www.youtube.com/watch?v=bUiBC8c1h4M>. Acesso em: 04/02/2020.

40 A instalação de tais objetos técnicos para atuação de uma empresa com capital global, com o projeto financiado e pensado inclusive a partir de relações de proximidade com o Estado Nacional brasileiro; tendo funções e intenções absolutamente predeterminadas; com uma enorme carga de informação; indispensável para que participem das formas de trabalho hegemônico; a serviço do trabalho mais produtivo economicamente; evoca a discussão sobre o espaço como um conjunto indissociável de sistemas de objetos e sistemas de ações, travada por Santos (1996). Essa interpretação permite compreender, 
entre outras questões, que o espaço está, devido à incessante sucessão de objetos, sempre mudando sua fisionomia, sua fisiologia, suas aparências, estruturas e relações.

Destaca-se, de antemão, que há uma distinção gigantesca dos tempos naturais para os tempos atuais, do meio técnico-científico-informacional, pois antes, em outros tempos, com outros sistemas técnicos, os objetos eram pouco numerosos, estavam em comunhão com o corpo humano e eram subordinados a estes corpos. Agora vive-se junto com os objetos técnicos, mas eles, os objetos, se apoderam do cotidiano humano, sendo uma relação prática, não profunda (SANTOS, 1996). Vive-se, no atual sistema técnico, cercado de objetos criados a partir de pesquisas científicas altamente intencionais, que não foram descobertas do acaso ou de experiências desprovidas de racionalidade.

42 Os objetos instalados em Santa Cruz, pela CSA, fazem parte de um grupo de objetos criados deliberadamente com a intenção mercantil, movidos por uma informação concebida cientificamente, através de um sistema de ações subordinado à mais-valia mundial. Santos (1996, p.216) salienta que "um objeto técnico nasce porque uma série de operações, intelectuais, técnicas, materiais, sociais e políticas convergem para sua produção".

O autor discorre sobre a intencionalidade de criação dos objetos ser ditada por lógicas mercantis, dando o exemplo das hidrelétricas, que aparecem como esperança de salvação da economia, de integração com o mundo, segurança de progresso, sendo símbolos que permitem partes da sociedade aceitarem a racionalidade do objeto, mas que, na realidade, pode elevar os níveis de conflitos, numa correlação de força com a natureza e comunidades tradicionais, além de impor relações radicalmente desiguais de apropriação do espaço. Quando a CSA, por exemplo, instala equipamentos nas calhas dos rios, para aumentar a circulação de grandes embarcações, os trabalhadores que atuam com pesca artesanal na Baía de Sepetiba têm suas atividades impedidas ou dificultadas. Emerge, portanto, um conflito que envolve diferentes sistemas técnicos e diferentes relações com os rios e com a baía. O relatório do PACS (2012) aponta que os terminais portuários e a grande movimentação em torno deles criaram zonas de exclusão de pesca, ou seja, áreas em que, por motivos de segurança, a prática da pesca ficou proibida.

O enorme terminal portuário que avança $4 \mathrm{~km}$ mar adentro, impede, citando um exemplo de problemática e tensão, que os mastros dos barcos dos pescadores passem por debaixo da ponte. Assim, para ir de um ponto ao outro, em uma área onde tradicionalmente circulavam livremente, os pescadores precisam contornar a construção para chegar ao outro lado. Em audiência na ALERJ, em 2011, noticiada pelo jornal O Globo ${ }^{13}$, pescadores inclusive culparam a siderúrgica CSA pela falta de peixes na Baía de Sepetiba, mostrando tamanha tensão entre duas lógicas econômicas completamente distintas, com técnicas de tempos e imposições diferentes. Jaci Nascimento, pescador que, em 2011, alguns anos depois do início das obras, já trabalhava como ajudante de pedreiro para sustentar a família, destacou, na audiência, que antes da construção da ponte, em 2006, costumava pescar cerca de $75 \mathrm{~kg}$ de peixe num dia, mas em 2011 já não pegava nada, porque a CSA havia proibido a pesca no Rio São Fernando, dizendo ser proprietária da área.

45 Portos e redes ferroviárias, que são objetos absolutamente racionais e sistêmicos, instalados na região da baía, apontam, portanto, para um contraste que intensifica um embate de lógicas econômicas distintas, baseadas em sistemas técnicos distintos, como 
é o caso das atividades siderúrgicas se sobrepondo sob as atividades pesqueiras, antes característica tradicional da região. O próprio Santos (1996) diz que esses sistemas técnicos contemporâneos tendem a competir vantajosamente com os anteriormente instalados, para impor ao uso do território ainda mais racionalidade instrumental, com fortíssimas marcas de uso da ciência, da tecnologia e da informação. Desse modo, criase uma tensão nos objetos do conjunto, paralela à tensão que se levanta, dentro da sociedade, entre ações hegemônicas e ações não hegemônicas.

Ações racionais, movida por atores hegemônicos globais e por uma racionalidade obediente à razão do instrumento, espanta toda forma de espontaneidade da vida, produzindo um cotidiano mecanizado, tanto na vida coletiva, quanto na condução da vida individual. Atores hegemônicos, com conteúdo baseado em ciência e técnica, coordenam ações, no tempo e no espaço, através da informação, o que indica, segundo Santos (1996, p.233), "o momento e o lugar de cada gesto e sugerindo as séries temporais e os arranjos territoriais mais favoráveis a um rendimento máximo da tarefa projetada". Conhecer o planeta permite a certos atores uma descoberta dos lugares para exercerem melhor determinadas atividades, como, por exemplo, uma siderúrgica com tamanho potencial produtivo numa baía na borda metropolitana do Rio de Janeiro, que é uma região estratégica de um país que estava apostando, no momento de sua implantação, num modelo de desenvolvimentismo que, embora preocupado com questões sociais, carregava contradições e paradigmas do capitalismo contemporâneo.

\section{O Eixo Santa Cruz - Itaguaí: metropolização do espaço e a consolidação do Extremo Oeste Metropolitano Fluminense}

47 Para Lefebvre $(1968 ;$ 1970), problematizando a questão urbana a partir da industrialização e do que ele chamou de implosão-explosão, nasceu um processo no qual o urbano dominou e absorveu a produção agrícola, convertida em produção industrial e subordinada às lógicas e demandas da urbe, dando forma à chamada urbanização completa da sociedade. Lencioni $(2008 ; 2015)$ mostra que, com os avanços técnicos e as mudanças internadas do sistema capitalista, principalmente advindas da ascensão do neoliberalismo (HARVEY, 2005), que deu a atual roupagem da globalização, nasce uma fase ainda mais avançada do processo de urbanização, denominada metropolização do espaço. De maneira figurativa, "é como se a metropolização do espaço se constituísse em uma segunda natureza da urbanização, no sentido de uma urbanização com nova essência e substância" (LENCIONI, 2015, p.7).

$\mathrm{Na}$ análise de Lencioni (2015) existe no processo de metropolização do espaço uma nebulosa urbana. "Como nebulosa, o fenômeno urbano apresenta-se esgarçado, rompido, com porosidades e descontinuidades face a um quadro de volatilidade permanente" (LENCIONI, 2015, p.9). Faz-se presente um cenário de fragmentação e totalidade que a autora, com base em Lefebvre, remete ao espaço capitalista como sendo homogêneo, fragmentado e hierarquizado. Sendo assim, é a integração entre as partes, através das redes, que evidencia o lócus para apreensão dos limites e possibilidades dessas extensões presentes na urbanização contemporânea. As metrópoles do Rio de Janeiro e de São Paulo constituem as principais cidades de uma nebulosa urbana onde se desenvolve a urbanização regional de maior expressão no 
Brasil e no hemisfério sul (LENCIONI, 2015), com sua ampla e importante rede de influência político-econômica para o país.

O bairro Santa Cruz está inserido nesta nebulosa urbana pela parte do Rio de Janeiro e é banhado pela Baía de Sepetiba, o que possibilitou as atividades portuárias e foi base para a implantação do Distrito Industrial de Santa Cruz, durante a década de 1970. Neste período, enquanto a crise do sistema fordista-keynesiano despontava nos países do capitalismo central, no Brasil vivia-se uma acelerada urbanização e a economia apresentava expressivo crescimento industrial. o país vivia um contexto no qual o poder político era centralizado e orientava as políticas de desenvolvimento, inclusive regionais e urbanas. Já no final do Século XX, principalmente na década de 1990, iniciava um momento em que novos processos emergem, com profundas alterações nas relações sociais de produção advindas do neoliberalismo, e as transformações urbanas e regionais tomam outras proporções. O Bairro Santa Cruz e seu longo processo de incorporação técnica, com urbanização e industrialização, está inserido e faz parte dessas transformações.

50 Naquele contexto de uma metrópole brasileira dos anos 1970, o Distrito Industrial de Santa Cruz se instalou e absorveu empresas como a Cosigua (Grupo Gerdau), White Martins e a Casa da Moeda do Brasil (DAMAS, 2008). Atualmente, segundo a Associação das Empresas do Distrito Industrial de Santa $\mathrm{Cruz}^{14}$, o distrito tem dezessete empresas associadas, contando inclusive com algumas de atuações globais. A partir de 2014, por exemplo, nele, a fábrica de turbinas da Rolls Royce, companhia britânica líder mundial em sistemas de energia, passou a fabricar turbogeradores com turbinas a gás, que são destinados a produzir energia nas plataformas de petróleo da Petrobras.

Santa Cruz e seus arredores são expoentes deste momento de inserção brasileira, a partir ainda dos anos de 1990 e ampliadas durante os governos petistas, nas lógicas dessa globalização, que tem a tecnologia, a economia internacionalizada e a metropolização do espaço como importantes características. As rugas presentes são difusas e as características dos espaços se diluem facilmente, pois na borda da metrópole em que se encontra, observa-se uma contínua e progressiva área de transição, um misto de atividades, mas que, de certa forma, estão conectadas regionalmente e respondem à própria metrópole.

No interior desta nebulosa metropolitana, Santa Cruz está conectado às lógicas industrias e regionais da cidade de Itaguaí e adjacências, estando incluso, ainda e, portanto, na logística urbana-regional do Extremo Oeste Metropolitano Fluminense (OLIVEIRA, 2015). Itaguaí, indicado por Lencioni (2015) como um dos municípios fluminenses componentes da megarregião, está conectado ao Distrito Industrial de Santa Cruz, evidenciando que as atividades industriais do bairro em questão estão inseridas nas mesmas lógicas regionais que as atividades pertencentes à cidade vizinha. Este município também é banhado pela Baía de Sepetiba, onde se mantém as importantes atividades do Complexo Portuário de Itaguaí. Percebe-se que a proximidade das atividades pode gerar influências reciprocas entre Itaguaí e o bairro carioca, bem como por parte da rede de infraestrutura e de comunicação viária entre os dois. Destacam-se nesse contexto a Rodovia Rio-Santos (BR 101), o recém inaugurado Arco Metropolitano (BR 493), o ramal ferroviário de Santa Cruz, o Porto de Itaguaí, além das áreas urbanas respectivas.

53 A CSA, assim como a citada Rolls Royce, alimenta e participa ativamente dos fluxos globais de mercadoria e informações e promove impactos significativos sobre o 
aumento da demanda por mão-de-obra, a expansão do setor terciário e o aquecimento do mercado imobiliário na cidade de Itaguaí, trazendo consequências não só para o bairro carioca que é o seu território especifico de atuação (OLIVEIRA \& ROCHA, 2014). Isso se dá justamente por suas atividades industriais serem indissociáveis da mesma lógica regional. Na figura 1, que mostra os projetos planejados para a região da Baía de Sepetiba e foi destacada aqui anteriormente, é possível também observar a proximidade das atividades industriais de Santa Cruz e de Itaguaí.

Oliveira (2015) aponta a "Região Logístico-Industrial do Extremo Oeste Metropolitano Fluminense", e destaca articulações encadeadas por caminhos rodoviários, ferroviários e portuários que conectam esta região à metrópole, e/ou à "Nebulosa Metropolitana Rio de Janeiro - São Paulo" (LENCIONI, 2015). Essas atividades do eixo Santa Cruz - Itaguaí apresentam-se como um complexo industrial portuário funcionando a todo vapor no Extremo Oeste Metropolitano Fluminense, que, por sua vez, viveu um processo de industrialização com características bastante peculiares da borda metropolitana, como área de expansão, influência e como polo de propagação da própria metrópole (OLIVEIRA, 2015). Essa região é cortada e integrada a outras regiões do estado e do país por diversas vias expressas, como a Rodovia Presidente Dutra (BR-116), o recente Arco Metropolitano Fluminense (BR-493), a Avenida Brasil / Rio-Santos (BR-101) e a antiga estrada Rio-São Paulo (BR-465), além de ter caminhos portuários e ferroviários importantes para a logística da nebulosa urbana Rio de Janeiro - São Paulo (OLIVEIRA, 2015).

55 Sendo assim, dentro da nebulosa urbana dispersa, com fragmentação e unidade, Santa Cruz, assim como Itaguaí e todo o Extremo Oeste Metropolitano Fluminense, se reestruturou, apresentando grande área disponível, infraestrutura e capacidade logística rodoviária, ferroviária e portuária, agilidade na implantação do projeto, menores custos operacionais e incentivos fiscais (OLIVEIRA, 2015), se colocando, na borda da metrópole, como área de atração de investimentos neste contexto de guerra dos lugares (SANTOS, 1996) da globalização contemporânea, o que dá outras proporções às suas recentes configurações espaciais associadas, principalmente, ao novo desenvolvimentismo apontado por Mercadante (2010).

\section{Considerações Finais}

Os objetivos mercadológicos de grandes empresas muitas vezes ficam invisíveis ao todo, camuflados por discursos e propagandas que elevam uma falsa preocupação com a vida miúda de populações tradicionais espalhadas ao redor de objetos técnicos monumentais, como uma estrutura portuária com intensa atividade se impondo sobre pescadores. Santos (1996) salienta que os grandiosos objetos técnicos têm um discurso que vem de sua estrutura e revela sua funcionalidade. É um discurso do uso, mas, também, o da sedução. Essa legitimação prévia tornou-se necessária para que a ação proposta seja mais docilmente aceita e mais ativa se torne na vida social. Esse discurso, de vital importância para efetuar as atividades, se torna presente em todos os lugares onde a modernidade se instala com todo seu aparato. Basta observar os discursos durante a inauguração da Companhia Siderúrgica do Atlântico em Santa Cruz. A chegada do conglomerado siderúrgico era legitimada através de falas que evocavam desenvolvimento econômico, social, sustentável, renda, emprego, entre outras beneficies sociais. Como se a empresa, através da racionalidade técnico-científica de 
suas ações e objetos, com altíssima produtividade e circulação de mercadorias, trouxesse um paraíso social a um lugar selvagem e infernal, desprovido de funcionalidade prática, que necessitasse da imposição técnico-científico-informacional para sua população triunfar.

O acesso da população de Santa Cruz a políticas públicas voltadas para direitos básicos está entre os mais precários do município (PACS; JUSTIÇA GLOBAL, 2017), mesmo no contexto de novo desenvolvimentismo. A aparição de moradoras(es) de Santa Cruz em jornais televisionados, por exemplo, esteve sempre acompanhada de manifestações por esgotamento sanitário, água tratada, asfalto, ar limpo, medicamentos, merenda e material escolar em aparelhos públicos. O bairro, durante o processo de chegada e instalação da CSA, é caracterizado por um centro, com comércio e meios de transporte precários, além conjuntos habitacionais, lavouras e plantas industriais ao seu redor. $\mathrm{O}$ movimento neste centro é absolutamente agitado: pedestres, camelôs em abundância, carros, motos, bicicletas, ônibus e vans disputam os espaços em um cotidiano conturbado.

Se levarmos em conta o ranking do Índice de Desenvolvimento Social do Rio de Janeiro de $2010^{15}$, Santa Cruz, com o IDS de 0,527, é um dos bairros da cidade com os piores índices de desenvolvimento humano entre os 162 bairros oficiais da cidade. Isso indica que essa lógica de uso do espaço, com todas as mudanças sociais e produtivas inerentes a ela, iniciada em meados do século passado e incentivada novamente neste início de Século XXI, acarretou em problemas e desequilíbrios que precisam ser plenamente entendidos e solucionados, considerando seus aspectos político-econômicos, pois enquanto a infraestrutura urbana do bairro e a renda da população próxima ao empreendimento são visivelmente precárias, a logística industrial avançou aceleradamente (PACS; JUSTIÇA GLOBAL, 2017).

Como visto, conexões com mercados nacionais e internacionais foram geradas através de redes assentadas no território: desde a linha férrea, passando pelas rodovias até chegar ao atual Porto de Itaguaí. Percebe-se, assim, a relevância do território de Santa Cruz para a logística industrial carioca, fluminense e brasileira. Entretanto, historicamente, essa relevância não se converteu em qualidade de vida para a população local, apesar de ser essa a promessa do novo desenvolvimentismo, com o megaempreendimento siderúrgico e outros empreendimentos, para o Extremo Oeste Metropolitano Fluminense.

60 Portanto, essa discussão que coloca seu enfoque central no Bairro de Santa Cruz Extremo Oeste Metropolitano Fluminense e na atuação da Ternium CSA, no contexto do novo desenvolvimentismo brasileiro apontado por Mercadante (2010), permite entender e contribuir em ações no campo da sociedade e das políticas públicas com relação aos modelos de desenvolvimento ao qual o bairro foi exposto, além de elevar e contribuir para expansão do conhecimento sobre um recorte espacial que participa ativamente da economia mundializada e possui centenas de contradições. $O$ provável próximo passo desta pesquisa será averiguar se e como os pilares do novo desenvolvimentismo, como democracia, sociedade do consumo e desenvolvimento sustentável, estiveram presentes de fato neste processo de instalação e atuação da Ternium CSA em Santa Cruz. 


\section{BIBLIOGRAFIA}

CARVALHO, L. Valsa Brasileira: Do boom ao caos econômico. São Paulo: Todavia, $1^{\mathrm{a}}$ ed., 2018.

DAMAS, E.T. Distritos industriais da cidade do Rio de Janeiro: gênese e desenvolvimento no bojo do espaço industrial carioca. 2008. 143f. Dissertação (Mestrado em Geografia) - Universidade Federal Fluminense, Niterói, 2008.

FURTADO, C. Introdução ao Desenvolvimento: enfoque histórico-estrutural. $3^{a}$ ed. Rio de Janeiro: Paz e Terra, 2000.

GUIMARÃES, V.T. O licenciamento ambiental prévio e a localização de grandes empreendimentos: o caso da TKCSA em Santa Cruz, Rio de Janeiro, RJ. Tese (mestrado) - Universidade Federal do Rio de Janeiro, Instituto de Pesquisa e Planejamento Urbano e Regional, 2011.

HARVEY, D. O Neoliberalismo: história e implicações. São Paulo: Loyola, 2008 [2005].

LEFEBVRE, H. A Revolução Urbana. Belo Horizonte: Editora UFMG, 2002 [1970].

O Direito à Cidade. 5ํㅡㄹ ed. São Paulo: Centauro, 2008 [1968].

LENCIONI, S. Da metrópole como estratégia desenvolvimentista à metrópole como sobrevida do capitalismo. In: PEREIRA, Paulo César Xavier; Hidalgo, Rodrigo. Producción inmobiliaria y reestructuración metropolitana en América Latina. Santiago: PUC-Chile, 2008, p. 41-54. . Urbanização difusa e a constituição de megarregiões. O caso de São Paulo-Rio de Janeiro. Rio de Janeiro: e-metropolis, n. 22, 2015, p. 6-15.

MERCADANTE, A. As bases do Novo Desenvolvimentismo: análise do governo Lula. Tese (Doutorado em Economia), Programa de Pós-Graduação em Ciência Econômicas, Instituto de Economia, UNICAMP - Universidade Estadual de Campinas, 2010.

OLIVEIRA, A; RODRIGUES, A. Industrialização na periferia da região metropolitana do Rio de Janeiro: novos paradigmas para velhos problemas. Medelín, Colômbia: Semestre Económico, v. 12, n.24 [Edición Especial), 2009, p.127-143.

OLIVEIRA, L. D. de. A emersão da região logísticoindustrial do Extremo Oeste Metropolitano fluminense: reflexões sobre o processo contemporâneo de reestruturação territorial-produtiva. Rio de Janeiro: Espaço e Economia [online], n. 7, 2015.

Geopolítica ambiental: a construção ideológica do desenvolvimento sustentável (1945-1992). Rio de Janeiro: Autografia, 2019.

OLIVEIRA, L. D. de; ROCHA, A. “Neodesenvolvimentismo" e reestruturação produtiva. Porto: Faculdade de Letras da Universidade do Porto, 2014, p. 126 - 142.

PACS. Companhia Siderúrgica do Atlântico - TKCSA: Impactos e Irregularidades na Zona Oeste do Rio de Janeiro. PACS, $2^{\mathrm{a}}$ edição, 2009.

. Companhia Siderúrgica do Atlântico - TKCSA: Impactos e Irregularidades na Zona Oeste do Rio de Janeiro. PACS, $3^{\mathrm{a}}$ edição, 2012.

PACS; JUSTIÇA GLOBAL. Violações de Direitos Humanos na Siderurgia: o caso TKCSA. Rio de Janeiro, PACS e Justiça Global, 2017.

PERDIGÃO, I.A.S. Os investimentos financeiros na região da Baía de Sepetiba e as articulações com o desenvolvimento territorial: uma breve nota. Belo Horizonte: XVI ENANPUR, st 1, 2015. 
PINTO, J.B. O papel da Responsabilidade Social Empresarial em cenários de conflitos ambientais siderúrgicos - O caso da TKCSA na periferia carioca de Santa Cruz. IV Congresso Brasileiro de Estudos Organizacionais, Porto Alegre, RS, 2016.

SANTOS, M. A Natureza do Espaço: Técnica e tempo. Razão e Emoção - 4. ed. 8. reimpr. São Paulo, Editora da Universidade de São Paulo, 2014 [1996]. 384p.

\section{NOTAS}

1. <https://www.em.com.br/app/noticia/economia/2017/02/22/internas_economia, 849399/socia-da-usiminas-ternium-compra-a-siderurgica-csa-por-1-5-bilhaode.shtml>. Acesso em 06/11/2019.

2. Carta ao povo brasileiro foi o título dado a um texto assinado em junho de 2002 pelo então candidato à presidência da república do Brasil, Luiz Inácio Lula da Silva, assegurando que, em caso de sua vitória, a sua agremiação, o PT, respeitaria os contratos nacionais e internacionais, evitando um caos social, como era vendido pela elite e pela grande imprensa brasileira. Fonte: < https://www1.folha.uol.com.br/folha/ brasil/ult96u33908.shtml>. Acesso em 08/01/2020.

3. Vale destacar que a Ternium CSA aparece na figura como TKCSA, pois até 2017 a Companhia pertencia à Thyssen-Krupp.

4. Santos, Milton. Guerra dos lugares. Folha Online, 1999. Disponível em: <https:// www1.folha.uol.com.br/fol/brasil500/dc_3_5.htm> . Acesso em: 16/01/2020.

5. Fonte: BNDES financia com $\mathrm{R} \$ 332,8$ milhões obras da CSN no Porto de Sepetiba. Disponível em:< https://www.bndes.gov.br/wps/portal/site/home/imprensa/noticias/ conteudo/20050720_not183_05>. Acesso em 21/01/2020.

6. Fonte: BNDES aprova financiamento de $\mathrm{R} \$ 407,7$ milhões para construção do Porto Sudeste, da LLX. Disponível em: <https://www.bndes.gov.br/wps/portal/site/home/ imprensa/noticias/conteudo/20100105_porto_sudeste> Acesso em: 21/01/2020

7. Fonte: BNDES financia com $\mathrm{R} \$ 1,48$ bilhão complexo siderúrgico da ThyssenKrupp em Santa Cruz (RJ). Disponível em: <https://www.bndes.gov.br/wps/portal/site/home/ imprensa/noticias/conteudo/20070620_not141_07>. Acesso em: 21/01/2020.

8. NUNES, Fernanda. MP abre investigação sobre concessões fiscais à CSA. O Estado de S.Paulo, 2016. Disponível em: <https://economia.estadao.com.br/noticias/geral,mpabre-investigacao-sobre-concessoes-fiscais-a-csa,10000070347>. Acesso em: 24/01/2020.

9. MOURA, Iara; RODRIGUES, Isabelle. A realidade por trás da Ternium. Le Monde Diplomatique Brasil, 2018. Disponível em: https://diplomatique.org.br/a-realidade-portras-da-ternium-brasil/>. Acesso em 24/10/2020.

10. Companhia Siderúrgica do Atlântico é inaugurada na Zona Oeste do Rio. Disponível em: < http://riodejaneiro.rio/web/guest/exibeconteudo?id=888394>. Acesso em: 04/02/2020

11. ThyssenKrupp CSA é inaugurada no Rio de Janeiro. Disponível em: < https:// tnpetroleo.com.br/noticia/thyssenkrupp-csa-e-inaugurada-no-rio-de-janeiro/>. Acesso em: 24/01/2020.

12. Vídeo: ThyssenKrupp CSA(TKCSA) - Processo Siderúrgico. Disponível em: <https:// www.youtube.com/watch?v=bUiBC8c1h4M>. Acesso em: 04/02/2020. 
13. Em audiência na Alerj, pescadores culpam siderúrgica CSA pela falta de peixes na Baía de Sepetiba. Disponível em: <https://oglobo.globo.com/rio/em-audiencia-na-alerjpescadores-culpam-siderurgica-csa-pela-falta-de-peixes-na-baia-de-sepetiba-2875859>. Acesso em: 05/02/2020.

14. AEDIN. Associados. Associação das Empresas do Distrito Industrial de Santa Cruz, 2018. Disponível em: http://www.aedin.com.br/portal/associados/. Acesso em dezembro de 2018.

15. IPP. Índice de Desenvolvimento Social - IDS (2010). Aplicativo Bairros Cariocas. Disponível em: <http://pcrj.maps.arcgis.com/apps/MapJournal/index.html? appid=096ae1e5497145838ca64191be66f3e3\#>. Acesso em 18/05/2018.

\section{RESUMOS}

Este artigo se debruça sobre a discussão que Mercadante (2010) designou "novo desenvolvimentismo brasileiro" e sobre a instalação da Companhia Siderúrgica do Atlântico no bairro de Santa Cruz, Rio de Janeiro, RJ. Tal iniciativa representa, nesse contexto políticoeconômico brasileiro, o novo desenvolvimentismo fomentado pelo Estado, juntamente com o empresariado nacional e internacional, com a construção de imenso polo industrial e complexo portuário voltado à exportação de commodities minerais e produtos siderúrgicos no Extremo Oeste Metropolitano Fluminense (OLIVEIRA, 2015). O primeiro empreendimento desse polo industrial foi a Companhia Siderúrgica do Atlântico - Ternium CSA. O enfoque desse estudo, analisando o contexto de tais políticas e ações do Estado, ajuda a entender e evidenciar as vantagens oferecidas à empresa, bem como as mudanças nas dinâmicas espaciais do bairro e os investimentos em infraestrutura para as atividades do conglomerado industrial, siderúrgico e portuário, além de debater a consolidação da borda metropolitana e do que se identifica como o eixo Santa Cruz - Itaguaí.

This article focuses on the discussion posed by Mercadante (2010), called "new Brazilian developmentalism" and on the installation of Companhia Siderúrgica do Atlântico in Santa Cruz, Rio de Janeiro, RJ. The initiative represents in the Brazilian political-economic context the socalled new developmentalism, put forward by the State, together with national and international entrepreneurship, with the construction of an immense industrial pole and a port complex focused on the export of mineral commodities and steel products in the in Rio de Janeiro state's west end metropolitan area (OLIVEIRA, 2015). The first enterprise of this industrial pole was Companhia Siderúrgica do Atlântico - Ternium CSA. This approach, analyzing the context of State policies and actions, helps to understand and highlight the advantages offered to the company; as well as changes in the spatial dynamics of the neighborhood and investments in infrastructure for the activities of the industrial, steel and port conglomerate; besides debating the consolidation of the metropolitan border and what is identified as the Santa Cruz - Itaguaí axis.

Cet article se concentre sur la discussion que Mercadante (2010) a qualifiée de " nouveau développementisme brésilien » et sur l'installation de Companhia Siderúrgica do Atlântico dans le quartier de Santa Cruz, Rio de Janeiro, RJ. Telle initiative représente, dans ce contexte politico- 
économique brésilien, le nouveau développementisme encouragé par l'État, en collaboration avec le milieu des affaires nationaux et internationaux, avec la construction d'un immense pôle industriel et d'un complexe portuaire destiné à l'exportation de matières premières minérales et de produits sidérurgiques dans l'Extrême Ouest Métropolitain du Rio de Janeiro (OLIVEIRA, 2015). La première entreprise de ce pôle industriel a été la Companhia Siderúrgica do Atlântico Ternium CSA. L'approche de cette étude, analysant le contexte de telles politiques et actions de l'État, permet de comprendre et de mettre en évidence les avantages offerts à l'entreprise, ainsi que les évolutions de la dynamique spatiale du quartier et les investissements en infrastructures pour les activités du conglomérat industriel, sidérurgique et portuaire, en plus de discuter de la consolidation de la bordure métropolitaine et de ce qui est identifié comme l'axe Santa Cruz Itaguaí.

Este artículo se centra en la discusión que Mercadante (2010), llamó "nuevo desarrollismo brasileño" y la acerca de la consiguiente instalación de Companhia Siderúrgica do Atlântico en Santa Cruz, Río de Janeiro - RJ. Esta iniciativa representa, en este contexto político-económico brasileño, el nuevo desarrollo promovido por el Estado, junto con el negocio nacional e internacional, con la construcción de un inmenso complejo industrial de polos y puertos centrado en la exportación de commodities minerales y productos siderúrgicos en el Extremo Oeste Metropolitano Fluminense (OLIVEIRA, 2015). El primero emprendimiento de este centro industrial fue la Companhia Siderúrgica do Atlántico - Ternium CSA. El enfoque de este estudio, analizando el contexto de tales políticas y acciones del Estado, ayuda a entender y resaltar las ventajas ofrecidas a la empresa, así como los cambios en la dinámica espacial del barrio y las inversiones en infraestructura para las actividades del conglomerado industrial, siderúrgico y portuario, además de discutir la consolidación del borde metropolitano y lo que se identifica como el eje Santa Cruz - Itaguaí.

\section{ÍNDICE}

Mots-clés: Nouveau développementisme ; Santa Cruz ; Companhia Siderúrgica do Atlântico Ternium CSA ; Extrême Ouest Métropolitain du Rio de Janeiro.

Keywords: New Developmentalism; Santa Cruz; Companhia Siderúrgica do Atlântico - Ternium CSA; Rio de Janeiro state's west end metropolitan area.

Palabras claves: Nuevo desarrollismo; Santa Cruz; Companhia Siderúrgica do Atlântico Ternium CSA; Extremo Oeste Metropolitano Fluminense.

Palavras-chave: Novo Desenvolvimentismo; Santa Cruz; Companhia Siderúrgica do Atlântico Ternium CSA; Extremo Oeste Metropolitano Fluminense.

\section{AUTOR}

\section{ANDRÉ LUIZ DO NASCIMENTO GERMANO}

Mestrando do Programa de Pós-Graduação em Geografia da Universidade Federal Rural do Rio de Janeiro (PPGGEO-UFRRJ) e membro do LAGEP - Laboratório de Geografia Econômica e Política da UFRRJ. E-mail: andreabcgermano@gmail.com. 